8. Melnychuk A. Detsentralizatsiia vlady: reforma №1 (analitychni zapysky)/A. Melnychuk, P. Ostapenko. - K.: TsOP "Hlobus" FOP Kravchenko Ya. O. - 2016. - 3 s.

9. Terytorialnyi rozvytok ta rehionalna polityka $\vee$ Ukraini: aktualni problemy, ryzyky ta perspektyvy administratyvno-finansovoi detsentralizatsii / NAN Ukrainy.
DU "Instytut rehionalnykh doslidzhen imeni M. I. Dolishnoho NAN Ukrainy"; nauk. redaktor V. S. Kravtsiv - L viv, 2017. - 120 s.

Надійшла до редколегії 17.06.19

Kyrylo Tulin, psychologist

Kyiv, Ukraine

\title{
SOCIO-PSYCHOLOGICAL FACTORS OF THE ACTIVITY OF TERRITORIAL COMMUNITIES IN THE CONDITIONS OF DECENTRALIZATION
}

The article analyzes democratic decentralization, which provides for the formation of local self-government councils of the appropriate level, which represent the interests of the inhabitants of a certain territory, and there are no subordination relations between the councils of different levels. It is analyzed that the first step of modern reforms in Ukraine was administrative-territorial reform and, accordingly, creation of united territorial communities. It is analyzed that among the main obstacles to the implementation of effective decentralization reform are low activity of citizens, their unwillingness to take responsibility and make decisions. It is the low activity of the communities that makes it possible to manage the decentralization process from above, by the regional leadership. The article is a study of socio-psychological factors of the activity of territorial communities in the conditions of decentralization. A number of problems were found which stimulated the increase of activity of territorial communities. The dynamics of increase in the number of OTs in 2015-2018 in all regions of Ukraine is analyzed. It is considered that financial decentralization has also become one of the main factors in increasing population activity. It is noted that a considerable part of the population of territorial communities are ready to participate in public events. Analyzed that the key advantage of the new status of communities in the context of decentralization is the significant increase in the financial resources they can dispose of. It is determined that the union of territorial communities in terms of administrative-territorial reform and decentralization of power has opened wide opportunities for the development of institutes of selforganization of the population and local self-government, change of the model of organized "from above" society, which is a mechanism of restraining the creative potential of the nation and blocking the self-realization of human life, to an organized "bottom" that eliminates the contradiction between the citizen and the state.

Keywords: activity, territorial community, decentralization, financial decentralization, self-organization of the population, public events.

Кирилл Тулин, психолог

Киев, Украина

\section{СОЦИАЛЬНО-ПСИХОЛОГИЧЕСКИЕ ФАКТОРЫ АКТИВНОСТИ ТЕРРИТОРИАЛЬНЫХ ОБЩИН В УСЛОВИЯХ ДЕЦЕНТРАЛИЗАЦИИ}

Исследованы социально-психологические факторы активности территориальных общин в условиях децентрализации. Выяснено ряд проблем, которые стимулировали повышение активности территориальных общин. Проанализирована динамика увеличения количества ОТГ в 2015-2018 ге. во всех областях Украины. Рассмотрено, что финансовая децентрализация также стала одним из основных факторов повышения активности населения. Отмечено, что значительная часть населения территориальных общин готовы участвовать в общественных мероприятиях.

Ключевые слова: активность, территориальная община, децентрализация, финансовая децентрализация, самоорганизация населения, общественные мероприятия.

Bulletin of Taras Shevchenko National University of Kyiv. Series "Psychology". № 1(10), pp. 103-106 (2019)

УДК 159.9.316

DOI: https://doi.org/10.17721/BSP.2019.1(10).26
ISSN 1728-3817

(C) Taras Shevchenko National University of Kyiv,

Publishing Center "Kyiv University", 2019

Київський національний університет імені Тараса Шевченка, Київ, Україна

\section{СУЧАСНІ ТЕНДЕНЦІЇ ВИВЧЕННЯ СУБ'ЄКТИВНОГО БЛАГОПОЛУЧЧЯ ОСОБИСТОСТІ В ПІДЛІТКОВОМУ ТА ЮНАЦЬКОМУ ВІЦІ}

Визначено терміни з питань психічного здоров'я й емоційного благополуччя підлітків та осіб юнацького віку. Описано основні тенденції дослідження психічного здоров'я і емоційного благополуччя як компонента суб'єктивного благополуччя молоді за останні десятиліття. Підлітковий вік розглянуто як критичний період розвитку з довгостроковими наслідками для здоров'я і благополуччя особистості. Найбільш значущі фактори для здоров'я підлітків виявляються в їхньому середовищі, а також у виборі й можливостях для покращення здоров'я або несприятливої поведінки, що притаманні сучасному суспільству. Взято до уваги фактори, що впливають на суб'єктивний та емоційний добробут (позбавлення сну, підвищення рівня стресу, соціальні відносини, вплив насильства). Сучасний світ і середовище розвитку людини невпинно змінюються, що суттєво впливає на благополуччя особистості та їі подальший розвиток. Такі зміни є важливими елементами стосовно подальшої успішної взаємодї̈ підлітків та юнаків, їх інтеграції в суспільстві.

Ключові слова: особистість, емоційне благополуччя, суб'єктивне благополуччя, підлітковий та юнацький вік, сучасні тенденції.

Постановка проблеми. Дослідження чинників які впливають на емоційне благополуччя та формування суб'єктивного благополуччя особистості в підлітковому та юнацькому віці $є$ необхідним у період, коли людина проходить етапи сепарації, самостановлення, самовизначення, створення власних життєвих планів та шляхів їх реалізації в умовах сучасного суспільства. Для подальшого успішного функціонування в житті $€$ важливим той досвід та фактори розвитку, які отримує особистість у період підліткового та юнацького віку.

Аналіз досліджень та публікацій. У ході підготовки статті були опрацьовані сучасні доробки зарубіжних авторів, дослідження та гіпотези вітчизняних дослідників. Особлива увага приділена напрацюванням E. L. Pollard,
P. D. Leeта A. Morgan стосовно підліткового благополуччя; групі вчених, які займались питанням особливостей розвитку в юнацькому віці, розвитку та психічного здоров'я CallK. T., MortimerJ. T. та Lerner R. M., GalambosN. L., a також, доробку вітчизняного вченого Л. С. Виготського.

Мета статті - висвітлити фактори впливу на емоційний компонент суб'єктивного благополуччя та дослідити його вплив на формування особистості в підлітковому та юнацькому віці.

Виклад основного матеріалу. Емоційне благополуччя як емоційна стабільність і стійкість $€$ показником психічного здоров'я та одним із основних елементів самовідчуття у повсякденному житті. Це важливий елемент суб'єктивного благополуччя людини, який $є$ необ- 
хідним для повноцінного життя особистості [1; 2]. Протягом останніх десятиліть дослідження благополуччя підлітків та юнаків привертає більше уваги та інтересу вчених у зв'язку із впливом на побудову подальшого життя людини та суспільства в цілому.

Центральним фактором у здоров'ї та благополуччі підлітків $€$ вплив установок оточення молоді в повсякденному житті. Емоційний компонент суб'єктивного благополуччя в підлітковому та юнацькому віці $€$ особливо важливим із кількох причин. Підлітки, які перебувають у хорошому емоційному стані та відчувають суб'єктивне благополуччя, мають вищі шанси вирости у дорослих, які будуть щасливі, упевнені в собі й дотримуватимуться здорового способу життя [2].

Підлітковий період та юність - найважливіші періоди розвитку. За цей час діти зазнають різних змін у тілі, включаючи структури мозку, а також нервової системи, що, у свою чергу, має наслідки для когнітивного й емоційного фрункціонування, мотивації та соціальної взаємодії [3]. Вплив статевого дозрівання, анатомофрізіологічної перебудови на психологічну та психофрізіологічну складову психіки особистості та усвідомлення або не усвідомлення цього стану в роботі організму й нервової системи, є передумовою відсутності суб'єктивного благополуччя. У більшості випадків, причиною відсутності суб'єктивного благополуччя $є$ неусвідомлена природа цього явища, нестача навички його розпізнавання та самоконтролю.

Е. Еріксон, розглядаючи процес розвитку суб'єкта в аналізованому періоді, зазначає, що причиною психологічної напруги $€$ суперечність внутрішніх, особистісних установок та прагнень із вимогами суспільної моралі та загальної атмосфрери суспільства [4]. Благополуччя, на думку Л. С. Виготського, є відчуттям підйому як спонукання до діяльності, придбання нових знань та навичок. Л. С. Виготський указував на те, що всі психічні функції підлітка діють не безсистемно, не автоматично і не випадково, а в певному алгоритмі, що спрямовується конкретними особистісними прагненнями, потягами та інтересами [5].

Щоб зрозуміти важливість емоційного благополуччя як компоненти суб'єктивного благополуччя підлітків, необхідно зрозуміти цей віковий період. Підлітковий та юнацький вік зазвичай визначається як початок періоду статевого дозрівання, фрізіологічної трансформації, яка дає хлопчикам і дівчаткам дорослі тіла і змінює спосіб їхнього сприйняття та взаємодії із протилежною статтю, а також власне самовідчуття [6]. Підлітковий, юнацький вік також $є$ періодом експериментів та першого досвіду: самостійність, перша тривала розлука з домом, перший сексуальний досвід, перехід від школи в університет, зміна соціальних ролей [7]. Звичайно, характер і особливості змін даного вікового періоду відрізняються між суспільствами, культурами, соціальними класами. Зауважимо, що підліткові роки $є$ періодом набуття незалежності, коли світ людини розширюється і включає нові особливості взаємодії. Вплив поза сім'єю стає все більш важливим. Беручи до уваги зміни, що відбуваються у XXI ст., і те, як швидко змінюється контекст життя молоді, важко не зауважити, що це має серйозні наслідки для їхнього здоров'я. Зміни на макрорівні, такі, як демографічні тенденції, розширення економічних диспропорцій, глобалізація, зміни в уряді та суспільстві, змінюють щоденні умови життя молоді. Ці зміни впливають на те, як підлітки проводять свої дні, на їх умови життя, навантаження в школі й університеті, навколишнє середовище; що, у свою чергу, впливає на здоров'я та суб'єктивне благополуччя [8]

Усесвітня організація охорони здоров'я (ВООЗ) запропонувала таке визначення для психічного здоров'я: "Це стан добробуту, в якому індивід реалізує свої власні здібності, може впоратися із повсякденними стреса- ми життя, здатний продуктивно і плідно працювати та робити свій внесок у спільноту".

Зарубіжні дослідники описують емоційне благополуччя як одну зі складових суб'єктивного благополуччя. Емоційне благополуччя, яке часто називають "гедонічним благополуччям", означає якість емоцій та переживань людини, тобто такі емоції, як смуток, тривога, турбота, щастя, депресія, стрес, гнів, радість, що призводить до неприємних або приємних почуттів і лежать в основі емоційного благополуччя. Інше визначення - це оцінка якості свого життя, яке стосується загальних думок, тенденцій та почуттів про своє життя та ставлення до нього тощо [9]

Інші ж дослідники розглядають два аспекти психічного здоров'я: позитивний (благополуччя і вміння справитись із труднощами) і негативний (симптоми та захворювання). Позитивне психічне здоров'я не означає відсутність симптомів, таких, як тривога або депресія, але також включає інші захисні фактори, такі, як щастя, самооцінка та збалансовані емоції [10].

Для юнаків, що живуть у світі, який характеризується швидкими змінами, важливо розуміти, що різні тенденції та зміни можуть впливати на їх емоційне благополуччя та суб'єктивний стан. Це не означає, що основні елементи психічного здоров'я змінилися із часом, проте це вказує на те, що внаслідок різних змін середовища та суспільних рухів, із яким сьогодні стикаються підлітки, виникають різні тенденції, відповідно, змінюється процес формування особистості.

Підлітки стикаються з різними складнощами, деякі 3 яких можуть бути легкими, наприклад: перехід в іншу школу, зустріч з новими однолітками, вивчення чогось нового, вирішення проблем, а інші можуть бути дуже руйнівними й негативними, наприклад, стихійне лихо, страждання внаслідок травми або нещасного випадку, знущання, розлучення у родині або смерті когось із близьких [11]. Підлітки, які живуть у конкурентному середовищі та з батьками, що дотримуються тоталітарного стилю виховання, можуть відчувати більш високий рівень стресу та напруги. Такий поспішний спосіб життя призводить до скорочення часу на творчість, яка дає поштовх розвитку таких здатностей, як спритність, фрізичний, когнітивний та емоційний розвиток [12].

Одним із основних джерел отримання повсякденного стресу в житті підлітків і осіб юнацького віку є завищенні вимоги та тиск 3 боку старших стосовно досягнень і успіхів у навчанні. Тиск, щоб отримати хороші оцінки, вступити у кращий 3ВО, здати гарно іспити, $€$ основним із джерел тривоги молоді XXI ст.

Тиск і очікування 3 боку старших демонструвати кращі результати, педантичне прагнення до досконалості може призвести до збільшення кількості годин, витрачених на навчання й виконання домашніх завдань замість того, аби покращувати комунікативні навички, розвивати власний емоційний інтелект та встановлювати взаємини з однолітками, що, у свою чергу, позитивно вплинуло би на самооцінку, фрізичний, емоційний стан та суб'єктивне благополуччя.

Іншим фрактором, який може погіршити емоційне благополуччя та, як наслідок, суб'єктивне благополуччя, $є$ недостатній сон (депривація, низька якість, розлади). Надмірне навантаження навчальною діяльністю призводить до перевантаження когнітивної сфери та емоційної системи, що впливає на якість та кількість сну. Наявність достатньої кількості сну має суттєве значення для благополуччя людини, як для ії̈ фрізичного, так і для психічного здоров'я. Депривація сну негативно впливає на здатність людини належним чином розподіляти ресурси, увагу, керувати власними емоціями [13].

Формування здорових відносин із однолітками, батьками та вчителями може допомогти підвищити соціально-психологічний розвиток юнаків і підлітків, їх 
емоційне благополуччя. Молодь більшість свого часу проводить за навчанням, як основним видом своєї діяльності, що включає взаємодію з однолітками та викладачами. У контексті навчального середовища один із факторів, який може негативно вплинути на емоційне благополуччя - знущання з боку однолітків (фрізично, усно, соціально або в інтернеті).

Подібно до традиційних форм хуліганства, кібербулінг містить безліч соціально-психологічних та поведінкових проблем: почуття гніву, тривоги, депресії, пропуск занять і неможливість зосередитись, що часто погіршує емоційне благополуччя [14].

Одним із важливих елементів, що сприяють позитивному розвитку юнаків і підлітків, є здорові та стабільні міжособистісні стосунки [15]. Зокрема, у житті людини мало відносин, які є такими самими стійкими і вирішальними, як ті, що вони мають із батьками. Вони включають активне слухання, довіру та повагу, надання підтримки, захист, прихильність, що суттєво впливає на психічне й фрізичне здоров'я і соціальний розвиток.

Підтримка та спілкування з батьками і близьким оточенням впливає на емоційне благополуччя юнаків і підлітків. Одним із найсильніших предикторів високої задоволеності життям вказано час, який витрачали батьки для того, аби просто поговорити зі своєю дитиною.

Формування близької та надійної прив'язаності з батьками в ранньому дитинстві може сприяти розвитку в підлітковому віці та подальшому житті таких соціальних і емоційних навичок, як саморегуляція, автономія й кооперація, самоефективність і самооцінка [15]. Стабільна емоційна підтримка та відносини з батьками можуть служити захисним чи компенсаторним фактором під час життєвих труднощів, таких, як хронічний стрес, залякування, тривога й депресія.

Деякі фрактори ризику в сім'ях і середовищі їх проживання можуть бути шкідливими для емоційного благополуччя та психічного здоров'я підлітків. Це може включати бідність, фрінансові обмеження, соціальне виключення, вживання наркотиків, зловживання алкоголем, жорстоке поводження, психічні розлади в родині, розлучення, смерть близьких. Якщо такі негаразди та фактори ризику зберігаються і накопичуються протягом життєвого циклу особистості, то вона відчуватиме більший стрес та матиме вищий рівень імовірності виникнення поведінкових та емоційних труднощів, таких, як депресія, тривожні розлади, адикції та ідеї самогубства.

Фактори й середовище, в якому живе молодь XXI ст., швидко змінюються, що також впливає на їхнє благополуччя. Одним із прикладів $€$ новітні технології, які впливають на повсякденне життя підлітків, їх спосіб спілкування й навчання. Зростає кількість підлітків, які використовують і взаємодіють із однолітками за допомогою месенджерів і соціальних мереж. Хоча ці платформи мають певні переваги у вигляді взаємодії 3 різноманітними групами людей та можливостями спільного навчання, проте вони мають під собою певні ризики, наприклад кібер-домагання, кібер-залякування, крадіжка даних та інших проблем кібербезпеки.

Існує певна стурбованість тим, що високе використання соціальних мереж може мати негативні наслідки для емоційного благополуччя юнаків і підлітків. Хоча наявні дані ще обмежені й вимагають додаткових опрацювань, що створює подальший напрям нашої роботи, проте ми можемо зробити припущення, що помірне використання новітніх технологій та соціальних мереж не завдає високої шкоди для осіб підліткового та юнацького віку [16].

Висновки. Отже, визначено багато складових та характеристик, які підтримують емоційне благополуччя як компонент суб'єктивного благополуччя, такі, як самооцінка, мотивація, стійкість, самоефективність, надія і оптимізм, тоді як високий рівень тривожності, депресії і стресу може перешкоджати емоційному здоров'ю й добробуту.

Фактори, що впливають на емоційне благополуччя та формують самовідчуття підлітків та юнаків, це - сім'я, громада, однолітки, шкільне середовище та вчителі.

Здоров'я підлітків, як зазначалося раніше, регулюється повсякденними діями та оточенням, в якому вони ростуть і розвиваються. Перетворення у світовій економіці, уряді, сім'ях та технологіях, крім того що змінюють суспільства по всьому світі, ще й змінюють умови та фоктори життя підлітків.

Необхідно пам'ятати, що соціальні та економічні зміни у країні можуть відігравати певну роль у емоційному благополуччі людини через вплив на фінансові ресурси, а також зовнішні та внутрішні впливи і стурбованість майбутнім.

Подальші дослідження торкатимуться вивчення суб'єктивного благополуччя особистості в підлітковому та юнацькому віці, у структурі якого є когнітивний, емоційний, поведінковий компоненти, що дасть можливість розглянути його як цілісне, системно-структурне явище.

Список використаних джерел

1. Pollard E. L. and P. D. Lee. Child well-being: A systematic review of the literature // Social Indicators Research - 2003 - Vol 61/1 - P 59-78.

2. Morgan A. et al. Mental well-being in school-aged children in Europe: Associations with social cohesion and socioeconomic circumstances. 2007. - HSBC Forum background paper.

3. Giedd Jay N., M. Keshavan and T. Paus. Why do many psychiatric disorders emerge during adolescence?// Nature Reviews, Neuroscience. 2008. - Vol. 9/12. - P. 947-57.

4. Эрик Г. Эриксон Детство и общество : пер. с англ. - Изд. 2-е, перераб. и доп. - СПб.: ИТД "Летний сад", 2000. - 416 с.

5. Выготский, Л. С. История развития высших психических функций / Л. С. Выготский. - М.: Изд-во Юрайт, 2018. - 359 с.

6. Call K. T. \& Mortimer J. T. Arenas of comfort in adolescence: A study of adjustment in context. - Mahwah; N.J.: Erlbaum, 2001.

7. Lerner R. M. \& Galambos N. L. Adolescent development: Challenges and opportunities for research, programs and policies // Annual Review of Psychology. - 1998. - 49, P. 413-446.

8. Call K.T. et al. Adolescent Health and Well-Being in the Twenty-First Century: A Global Perspective // Journal of research on adolescence. 2002. - 12(1). - P. 69-98.

9. Kahneman D. and A. Deaton. "High income improves evaluation of life but not emotional well-being" // Proceedings of the National Academy of Sciences. - 2010. - Vol. 107/38. - P. 16489-93.

10. Korkeila, J. et al. Review article: Establishing a set of mental health indicators for Europe // Scandinavian Journal of Social Medicine. - 2003. Vol. 31/66 - P. 451-59.

11. Barnes A. J. Childhood Stress and Resilience // in M.R Korin (ed.), Health Promotion for Children and Adolescents. - 2016. - Springer, Boston, MA

12. Ginsburg Kenneth R. The importance of play in promoting healthy child development and maintaining strong parent-child bons // Pediatrics. 2007. - Vol. 119/1. - P. 182-91.

13. Alfarra R. et al. "Changes in attention to an emotional task after sleep deprivation: Neurophysiological and behavioral findings // Biological Psychology. - 2015. - Vol. 104. - pp. 1-7.

14. Tokunaga R. S. Following you home from school: A critical review and synthesis of research on cyberbullying victimisation // Computers in Human Behavior - 2010 - Vol. 26/3 - pp. 277-87.

15. Goldman-Mellor S. J. et al. Child mental health: Recent developments with respect to risk, resilience, and interventions // in M.R. Korin (ed.), Health Promotion for Children and Adolescents, Springer US. - 2016. P. 99-123.

16. Przybylski A. K. and N. Weinstein. A large-scale test of the goldilocks hypothesis: Quantifying the relations between digital-screen use and the mental well-being of adolescents // Psychological Science. - 2017

Надійшла до редколегії 13.06.19

Anna Khaleeva, postgraduate

Taras Shevchenko National University of Kyiv, Kyiv, Ukraine

\section{MODERN TENDENCIES OF STUDYING SUBJECTIVE WELL-BEING OF PERSONALITY IN ADOLESCENT AND YOUTH}

The article defines terms on mental health and emotional well-being of adolescents and adolescents, and outlines major trends in mental health and emotional well-being of young people over the past decades. The aim of the article is to highlight and establish the importance of emotional and 
subjective well-being in adolescence and youth, to identify their further influence on the formation of the personality and its full life. Adolescence is seen as a critical period of development with long-term effects on the health and well-being of the individual. It is stated that the central factor in the health and well-being of adolescents is the interaction of young people with their environment, with people and attitudes in their daily lives. The most important determinants of adolescents' health are in their environment, as well as the choices and opportunities for improving the health or adverse behaviors of today's society. Factors that influence on the subjective and emotional well-being (sleep deprivation, increased stress, social relationships, the impact of violence) have been taken into account. The components and characteristics that support emotional and subjective well-being are identified, such as: self-esteem, motivation, stability, self-efficacy, hope and optimism, while high levels of anxiety, depression and stress can interfere with emotional health and well-being. In determining the factors that affect the emotional and subjective well-being of adolescents and youths, it is important to take into account the multidimensional nature of well-being and what sources and factors form it. The main sources affecting the sense of self and overall well-being of a person in adolescence and youth are family, community, peers, school environment and teachers.

The modern world and the environment of human development are constantly changing, which has a significant impact on the well-being of the individual and its further development. Such changes are important elements for the continued successful interaction of adolescents and young people and their integration in society.

Keywords: personality, emotional well-being, subjective well-being, adolescence and adolescence, current trends.

Анна Халеева, асп.

Киевский национальный университет имени Тараса Шевченко, Киев, Украина

\section{СОВРЕМЕННЫЕ ТЕНДЕНЦИИ ИЗУЧЕНИЯ СУБЪЕКТИВНОГО БЛАГОПОЛУЧИЯ ЛИЧНОСТИ В ПОДРОСТКОВОМ И ЮНОШЕСКОМ ВОЗРАСТЕ}

Наведены определения, которые касаются психического здоровья и эмоционального благополучия подростков и лиц юношеского возраста. Описаны основные тенденции изучения психического здоровья и эмоционального благополучия как компонента субъективного благополучия молодежи за последние десятилетия. Подростковый возраст рассмотрен как критический период развития с долгосрочными последствиями для здоровья и благополучия личности. Наиболее значимые факторы для здоровья подростков находятся в среде их обитания, а также в выборе и возможностях улучшения здоровья или неблагоприятного поведения, которые присущи современному обществу. Приняты во внимание факторы, влияющие на субъективное и эмоциональное благополучие (лищение сна, повышение уровня стресса, социальные отношения, влияние насилия). Современный мир и среда развития человека постоянно меняется, что оказывает существенное влияние на благополучие личности и ее дальнейшее развитие. Такие изменения являются важными элементами относительно дальнейшего успешного взаимодействия подростков и юношей, их интеграции в обществе.

Ключевые слова: личность, эмоциональное благополучие, субъективное благополучие, подростковый и юношеский возраст, современные тенденции.

Bulletin of Taras Shevchenko National University of Kyiv. Series "Psychology". № 1(10), pp. 106-109 (2019)

УДК 336.56

DOI: https://doi.org/10.17721/BSP.2019.1(10).27
ISSN 1728-3817

(C) Taras Shevchenko National University of Kyiv,

Publishing Center "Kyiv University", 2019

Юлія Шатило, канд. психол. наук, доц., Олександра Громова, студ.

Національний авіаційний університет, Київ, Україна

\section{РОЗВИТОК ФАНДРАЙЗИНГУ ЯК ТЕХНОЛОГІЇ СОЦІАЛЬНОЇ РОБОТИ В УКРАЇНІ}

Висвітлено теоретичний аналіз наукової літератури із проблем використання фандрайзингу як технології соціальної роботи в сучасній Україні. Неприбуткові організацї̈ фактично виконують функцію соціальних посередників-реалізаторів соціальних ідей і програм, тобто вони діють між державою, комерційними фірмами і громадянами. Це все свідчить про важливість всебічного розвитку даного сектора економіки і для держави, і для бізнесу, і для суспільства.

Ключові слова: фандрайзине, неприбуткові організації, технологія соціальної роботи.

Постановка проблеми. Традиційно соціальна сфера в Україні - це сфера діяльності держави, яка відповідає за реалізацію соціальної політики. Останнім часом можна із впевненістю говорити про помітну роль некомерційних громадських організацій на ринку соціальних послуг у ході співробітництва та фрінансової допомоги державним установам соціальної сфери. Реалізація багатьох перспективних ідей та ініціатив за участю громадських організацій найчастіше пов'язані 3 наявністю джерел фінансування. Як правило, кількість ідей та пропозицій у багато разів перевищують фінансові можливості громадських організацій. Пошук джерел фрінансування та реальних донорських коштів для реалізації соціально орієнтованих та суспільно-значущих проектів $є$ проблемою більшості громадських організації в Україні. Проблема забезпеченості соціальних проектів джерелами безоплатного фрінансування наводить на усвідомлену необхідність фрормування цілеспрямованої стратегії пошуку засобів - організації фандрайзингу.

Фандрайзинг - практично нова сфрера діяльності для нашої країни. Вона розвинена в США та Європі, де розроблено різноманітну систему пільг та заохочень вкладникам в соціальну сферу, комерційним структурам, фондам чи приватним особам. Традиції вільного західного ринку заохочують фрілантропію. Соціальна сфера в Україні, як ніяка інша, потребує організованого фінансування із позабюджетних фондів. Для більш чіткої та профресійної організації залучення ресурсів спонсорів та донорів з'являються першокласні фрахівці, які вміють поповнювати бюджет громадських організацій.

Упровадження та використання технології фандрайзингу дозволить розширити фрінансові можливості установ соціальної сорери та, як наслідок, збільшити ефеектиність їхнього функціонування. Дисбаланс у фінансуванні громадських організацій є причиною для вивчення видів і особливостей використання фандрайзингу та їх упровадження на практиці в українських реаліях.

Аналіз останніх досліджень і публікацій. Теоретичну основу даного дослідження становили публікації таких зарубіжних і вітчизняних учених, як Дж. Д. Александер, К. Дж. Карлсон [4] (у своїх роботах розкривають три основних аспекти фандрайзингу - підготовку опису проекту, створення стратегії кампанії та забезпечення великих пожертвувань), А. Димнікова, А. Сарджента та Дж. Шанг (фандрайзинг відносин має на увазі погляд на донора/благодійника як на індивідуальність, пожертвування якого відображають його власні філантропічні цілі й інтереси, фрілантропічну ідентичність [12, с. 5].), А. Карпуніна [5] (франдрейзинг, у свою чергу, є драйвером розвитку самої благодійності), І. Мерсіянов, Н. Іванова, І. Корнєєва (у своїх роботах розглядають фандрайзинг як фактор сталого функціонування некомерційного сектора) [7], Г. Тульчинський, Л. Кильштендт тощо.

Невирішені раніше частини загальної проблеми. У багатьох західноєвропейських країнах i, особливо у 